\title{
EFFECT OF GENERAL MANAGER CHANGES ON FINANCIAL PERFORMANCE: A STUDY ON BIST 30 COMPANIES
}

\author{
DOI: $10.17261 /$ Pressacademia.2020.1358 \\ PAP- V.12-2020(22)-p.84-86
}

\author{
Mehmet Yusuf Gungor ${ }^{1}$, Ayben Koy ${ }^{2}$ \\ ${ }^{1}$ Istanbul Commerce University, Finance Institute, Department of Financial Economics, Sutluce Campus, Istanbul, Turkey. \\ mehmetyusufgungor@outlook.com.tr, ORCID: 0000-0001-6480-0929 \\ ${ }^{2}$ Istanbul Commerce University, Faculty of Business, Banking and Finance Program, Sutluce Campus, Istanbul, Turkey. \\ akoy@ticaret.edu.tr, ORCID:0000-0002-2506-6634
}

To cite this document

Gungor, M.Y., Koy, A. (2020). Effect of general manager changes on financial performance: a study on BIST 30 Companies. PressAcademia Procedia (PAP), V.12, p.84-86.

Permanent link to this document: http://doi.org/10.17261/Pressacademia.2020.1358

Copyright: Published by PressAcademia and limited licensed re-use rights only.

\begin{abstract}
Purpose- The decisions of the top managers of a company significantly affect the financial performance of that company. For companies, the general manager is actually the most valuable intellectual resource for that company. General managers' influence on strategies and organizational outcomes is critical. In this respect, the study is important and focuses on whether changes in the general manager have an impact on financial performance. There are many criteria for the selection of a new general manager. In this election, almost like a "horse race", companies can finish this job by choosing from among the inside candidates or buy the experience from outside. Candidates selected from the inside can act faster and on the spot because they know the company. External candidates, on the other hand, can make more agile and correct decisions because they have a pool of resumes and different experiences. This study aims to analyze the financial performance of companies included in the BIST30 index. When the literature is searched, the decisions of the company's top management and the status of the company, which are the main factors of this study, significantly affect the financial performance of the companies. The study is carried out to measure the financial performance impact based on the periods with a change of general manager. The focus and purpose of the study are to analyze the financial performance of the general manager change while analyzing whether the status of the company as a public/private company has an effect on financial performance. In this respect, the study is different from other studies.

Methodology- The design of the research covers companies with a change of general manager. The main body of the research consists of public companies included in the Borsa Istanbul (BIST) 30 index. First of all, within the scope of the literature examined on the effect of general manager changes on financial performance, variables such as ROA, ROE, Tobin's $Q$ are used as dependent variables and Leverage Ratio, Share Closing Price, General Manager Change, General Manager's Origin, General Manager's Experience and Number of Employees determined as. Data on firm performance indicators were obtained from the PDP (Public Disclosure Platform) electronic database, Thomson Reuters Eikon Data Terminal and independent audit reports of the companies. In order to measure the impacts better, data for the pre and post-change periods were also collected. In order to create a balanced panel set, 24 companies out of 30 companies included in the Borsa Istanbul (BIST) 30 index were included in the research. The reason why 6 companies are excluded from the scope of the analysis is that there are no general manager changes as of the quarter periods of 2011-2019, which were included in the scope of work in the relevant companies. The effects of the origins, experience, and status of the newly appointed general manager on the financial performance of the company as a public/private sector company were analyzed with panel data regression analysis. Descriptive statistics were created, panel unit root tests, Hausman test, and panel regression analysis were performed respectively in order to achieve the purpose of the study.

Findings- This study conducted on Borsa Istanbul (BIST) 30 Companies was not consistent in terms of regression results. First of all, within the scope of the analysis, it has been concluded that there is no significant relationship between the general manager changes and the financial performance of the company. While examining this effect, the selection of the general manager, which is frequently mentioned in the literature, by the internal or the external appointment was included in the analysis, and as a result, it was determined that the newly appointed general manager was selected through internal appointment and external appointment did not have an effect on financial performance. As a result of the study, a similar result was reached with the study conducted by Fanegan (2010) in the literature. According to the findings obtained from the analysis, it was concluded that the effect of being a Public/Private Sector company within the scope of general manager changes on financial performance was not found to be statistically significant. This result stands out as a point that diverges from the literature.

Conclusion- The effect of the changes in the general manager on the financial performance of the companies was found to be statistically insignificant for the 24 companies included in the BIST30 companies and the period 2011Q1-2019Q4. It should be noted that these findings were obtained for a relatively narrow sample in a developing economy and would not make sense on their own. In future studies,
\end{abstract}


sectors/companies with more general manager changes can be taken into account, and a sector in which the effect of gender change is also taken into account can be examined. In this way, more meaningful results on the subject can be achieved.

Keywords: General manager changes, financial performance, agency theory, bist30 companies, public-private separation. JEL Codes: M40

GENEL MÜDÜR DEĞişiMLERININ FINANSAL PERFORMANSA ETKISI: BIST 30 ŞíRKETLERi ÜZERINE BíR ÇALIŞMA

\section{ÖZET}

Amaç- Bir şirketin üst yöneticilerinin kararları o şirketin finansal performansını önemli derecede etkilemektedir. Şirketler için genel müdür, aslında o şirket için en değerli entelektüel kaynaktır. Genel müdürlerin stratejiler ve organizasyonel sonuçlar üzerindeki etkisi kritiktir. Çalışma, bu bakımdan önem kazanmakta olup genel müdür değişikliklerinin finansal performansa etkisi olup olmadığına odaklanmaktadır. Yeni genel müdür seçimi için birçok kriter vardır. Şirketler bu seçimde nerdeyse bir "at yarışı" gibi içeriden adaylar arasından seçimle bu işi bitirebilir ya da dışarıdan deneyimi satın alabilir. İçeriden seçilen adaylar, şirketi tanıdıkları için aksiyon almada daha hızı ıe yerinde hareket edebilirler. Dışarıdan adaylar ise özgeçmiş havuzuna sahip oldukları ve farklı deneyimlere sahip oldukları için daha atik ve doğru kararlar alabilirler. Bu çalışma, BIST30 endeksinde yer alan şirketlerin finansal performansını analiz etmeye yöneliktir. Literatür araştırması yapıldığında bu çalışmanın ana faktörleri olan şirket üst yönetiminin kararları ve şirketin statüsü şirketlerin finansal performansını önemli ölçüde etkilemektedir. Çalışma, genel müdür değişikliği olan dönemler baz alınarak finansal performans etkisini ölçmeye yönelik olarak yapılmaktadır. Çalışmadaki odak noktası ve amaç, genel müdür değişikliğinin finansal performansını analiz ederken, şirketin kamu/özel şirket statüsünde olması durumunun da finansal performansa etkisinin olup olmadığını analiz etmektedir. Yapılan çalışma bu yönüyle diğer çalışmalardan ayrışmaktadır.

Yöntem- Araştırmanın tasarımı, genel müdür değişikliği olan şirketleri kapsamaktadır. Araştırmanın ana kütlesini Borsa İstanbul (BıST) 30 endeksinde yer alan halka açık şirketler oluşturmaktadır. Öncelikle genel müdür değişikliklerinin finansal performans üzerindeki etkisi üzerine incelenen literatür kapsamında bağımlı değişken olarak ROA, ROE, Tobin's Q gibi değişkenlerin kullanıldığı, bağımsız değişken olarak da Kaldıraç Oranı, Hisse Kapanış Fiyatı, Genel Müdür Değişimi, Genel Müdürün Kökeni, Genel Müdürün Deneyimi ve Çalışan Sayısı olarak belirlenmiştir. Firma performans göstergelerine ilişkin veriler KAP (Kamuyu Aydınlatma Platformu) elektronik veri tabanından, Thomson Reuters Eikon Veri Terminalinden ve şirketlerin bağımsız denetim raporlarından elde edilmiştir. Etkilerin daha iyi ölçümlenebilmesi için, değişim öncesi ve sonrası dönemlere ait veriler de toplanmıştır. Dengeli panel set oluşturulması amacıyla Borsa İstanbul (BIST) 30 endeksinde yer alan 30 şirket üzerinden 24 şirket araştırmaya dâhil edilmiştir. 6 şirketin analiz kapsamı dışında bırakılma nedeni ise ilgili şirketlerde çalışma kapsamına alınan 2011-2019 yılları çeyreklik dönemleri itibarıyla genel müdür değişikliği bulunmuyor olmasıdır. Yeni atanan genel müdürün kökeninin, deneyiminin ve şirketin kamu/özel sektör şirketi olma durumunun finansal performansı üzerindeki etkileri panel veri regresyon analiziyle incelenmiştir. Çalışmanın amaca ulaşabilmesi için sırasıyla tanımlayıcı istatistikler oluşturulmuş, panel birim kök testleri, Hausman testi ve panel regresyon analizleri yapılmıştır.

Bulgular- Borsa İstanbul (BIST) 30 Şirketleri üzerine yapılan bu çalışma regresyon sonuçları itibarıyla tutarlı çıkmamıştır. Öncelikle, analiz kapsamında genel müdür değişiklikleri ile şirketin finansal performansı arasında anlamlı bir ilişki olmadığı sonucuna ulaşılmıştır. Bu etki incelenirken literatürde sıkça yer alan genel müdürün içeriden atanma veya dışarıdan atanma yoluyla seçilmesi analize dâhil edilmiş ve sonuç olarak yeni atanan genel müdürün içeriden atanma ve dışarıdan atanma yoluyla seçilmiş olmasının finansal performans üzerinde bir etkisi olmadığı saptanmıştır. Çalışmanın sonucunda literatürde yer alan Fanegan (2010) tarafından yapılan çalışma ile benzer bir sonuca ulaşılmıştır. Analiz sonucunda elde edilen bulgulara göre genel müdür değişiklikleri kapsamında Kamu/Özel Sektör şirketi olma durumunun finansal performansa etkisinin istatistiksel olarak anlamlı çıkmadığı sonucuna varılmıştır. Ulaşılan bu sonuç, literatürle ayrışan bir nokta olarak öne çıkmaktadır.

Sonuç- Genel müdür değişikliklerinin firmaların finansal performansı üzerinde etkisi BIST30 şirketleri içerisinde yer alan 24 şirket ve 2011 Q12019 Q4 dönemleri için istatistiksel olarak anlamsız çıkmıştır. Bu bulguların, gelişmekte olan bir ekonomide ve görece dar bir örneklem için elde edilmiş olması ve tek başına anlam ifade etmeyeceğini da belirtmek gerekir. İleride yapılacak olan çalışmalarda genel müdür değişiminin daha fazla olduğu sektörler/firmalar dikkate alınabilir, cinsiyet değişiminin etkisinin de göz önüne alındığı bir sektör incelenebilir. Bu şekilde konuyla ilgili daha anlamlı sonuçlara ulaşılabilir.

Anahtar Kelimeler: Genel müdür değişiklikleri, finansal performans, vekâlet teorisi, bıst30 şirketleri, kamu-özel ayrımı. JEL Kodları: M40

\section{REFERENCES}

Ataay, A. (2018). Implıcatıons Of Insıder And Outsıder Ceos On Fırm Performance: Evidence From Ceo Successıons From Turkey, Journal of Mehmet Akif Ersoy University Economics and Administrative Sciences Faculty, 5(5), 583-596.

Bennedsen, M., Nielsen, K.M., Perez-Gonzales, F. ve Wolfenson, D. (2007), Inside The Family Firm: The Role Of Families In Succession Decisions And Performance, The Quarterly Journal of Economics, 122(2), 647-691.

Berns, K.V.D. ve Klarner, P. (2017), A Review Of The CEO Succession Literature And A Future Research Program, Academy of Management Perspective, 31(2), 83-108. 
Boardman, A. E. ve Vining, A. R. (1989). Ownership and Performance in Competitive Environments: A Comparison of the Performance of Private, Mixed, and State-Owned, Journal of Law and Economics, 32(1), 1-33.

Cao, Q., Maruping, L.M. ve Takeuchi, R. (2006), Disentangling The Effects Of CEO Turnover And Succession On Organizational Capabilities: A Social Network Perspective, Organization Science, 17, 563-576.

Connelly, B.L., Ketchen, D.J., Gangloff, K.A., ve Shook, C.L. (2016), Investor Perceptions Of CEO Successor Selection In The Wake Of Integrity And Competence Failures: A Policy Capturing Study, Strategic Management Journal, 37, 2135-2151.

Fanegan, M. O. (2010). The buy or build decision in selecting a CEO's successor: A quantitative analysis of new CEO origin and subsequent corporate financial performance of fortune 500 companies. Dissertation, Capella University, 2010.

Finkelstein, S., Hambrick, D.C. ve Cannella, Jr., A.A. 2009. Strategic Leadership: Theory And Research On Executives, Top Management Teams, And Boards, New York, NY: Oxford University Press.

Gençtürk, M. (2003). Finansal Kriz Dönemlerinde İşletmelerin Hisse Yoğunluklarının Performanslarına Etkileri, Süleyman Demirel Üniversitesi i.i.B.F. Dergisi, 8(2), 213-251.

Güriş, S., Akay, E.Ç., Güriş, B. (2017). Eviews ile Temel Ekonometri. Der Yayınları.

Hambrick, D.C. ve Mason, P.A. (1984), Upper Echelons: The Organization As A Reflection Of Its Top Managers, Academy of Management Review, 9(2), 193-260.

Hambrick, D.C. (2007), Upper Echelons Theory: An Update, Academy of Management Review, 32(2), 334-343.

Haveman, H.A., Russo, M.V., ve Meyer, A.D. (2001), Organizational Environments In Flux: The Impact Of Regulatory Punctuations On Organizational Domains, CEO Succession, And Performance, Organization Science, 12, 253-273.

Karaevli, A. (2007), Performance Consequences Of New CEO “Outsiderness": Moderating Effects Of PreAnd Post-Succession Contexts, Strategic Management Journal, 28(4), 681-706.

Lauterbach, B., Vu, J. ve Weisberg, J. (1999), Internal Vs. External Successions And Their Effect On Firm Performance, Human Relations, 52(12), 1485-1504.

Ma, S., Seidl, D., ve Guérard, S. (2015). The new CEO and the post-succession process: An integration of past research and future directions. International Journal of Management Reviews, 17, 460-482.

Quang, D.X. ve Xin, W.Z. (2014). The Impact of Ownership Structure and Capital Structure on Financial Performance of Vietnamese Firms, International Business Research, 7(2), 64-71.

Sarıkovanlık, V., Koy, A., Akkaya, M., Yıldırım, H.H. ve Kantar, L. (2019). Finans Biliminde Ekonometri Uygulamaları. Seçkin Yayıncılık.

Suna, Z. ve Wang, Y. (2016). Does Ownership Structure Matter? Evidence From Firms' Excess Cash In China, The European Journal of Finance, 22(4-6), 463-483.

Thornton, P.H. ve Ocaiso, W. (1999), Institutional Logics, Greenwood, Royston, Oliver, Christine, Suddaby, Roy and Anderson, Kerstin S. In, The Sage handbook of organizational institutionalism, NY: Sage Publications Inc.

Tian, J., Haleblian, J., ve Rajagopalan, N. (2011), The Effects Of Board Human And Social Capital On Investor Reactions To New CEO Selection, Strategic Management Journal, 32, 731-747.

Yu, M. (2015). State Ownership And Firm Performance: Empirical Evidence From Chinese Listed Companies, China Journal of Accounting Research, 6, 75-87.

Zhang Y. ve Rajagopalan, N. (2003), Explaining New CEO Origin: Firm Versus Industry Antecedents, Academy of Management Journal, 46(3), 327-338.

Zhang Y. ve Rajagopalan, N. (2004), When The Known Devil Is Better Than An Unknown God: An Empirical Study Of The Antecedents And Consequences Of Relay CEO Successions, Academy of Management Journal, 47(4), 483-500.

Zhang Y. ve Rajagopalan, N. (2010), Once An Outsider, Always An Outsider? CEO Origin, Strategic Change, And Firm Performance, Strategic Management Journal, 31(3), 334-346. 